\title{
TRANSIENT ANALYSIS AND FATIGUE LIFE PREDICTION OF TUBESHEET
}

\author{
S. S. Pande ${ }^{1}$, P. D. Darade ${ }^{2}$, G. R. Gogate ${ }^{3}$ \\ ${ }^{1}$ Assistant Professor, Dept. of Mechanical Engineering, DYPCOE, Akurdi, Pune, Maharashtra, India \\ ${ }^{2}$ Assistant Professor, Dept. of Mechanical Engineering, SITS, Maharashtra, India \\ ${ }^{3}$ Professor, Dept. of Mechanical Engineering, Alard College of Engineering, Maharashtra, India
}

\begin{abstract}
The filtration process is widely used in various applications where the contaminants are to be removed from the working fluid of the system. This paper deals with the analysis and determination of the fatigue life of the tube sheet which is widely used in the filters as main supporting elements of the filter tubes. The application of the filters which is considered in this paper is of petro chemical industries. The specific application analyzed deals with the natural gas filtering immediately after it is mined. For analysis purpose static structural and transient dynamic modules are used and for fatigue life prediction, the ASME codes are referred. In the primary phase the calculation of dimensions of the tubesheet were of prime importance. The calculated dimensions of the tubesheet were then confirmed from the client for further process. In secondary phase the tubesheet was analyzed in static structural module for proper convergence and then was analyzed in transient dynamic module for peak values of stresses and deformation. These stress and deformation values are used for fatigue life prediction of the tubesheet. The fatigue life is predicted by using ASME codes. The last phase of the project concludes with the validation of FEA results by comparing the FEA results of hydro test in the virtual environment and the experimental results obtained from actual hydro test of the tubesheet conducted at the clients end.
\end{abstract}

Keywords: - Tubesheet, Transient Dynamic analysis, Fatigue Life, ASME codes, Hydro test. - ***

\section{INTRODUCTION}

In the conventional filtration process the gas is passed from one side of the filter tubes and the filtered gas is collected on the other side of the filter tubes. Generally the tubes used for filtration process are made of ceramic materials with tiny pores on it and hung along the open ends in the tubesheet. The total load of the tubes is bared by the tubesheet itself which is then assembled in the vessel. The filtration process is continuous. After continues filtering of gas, the filter tubes gets clogged which reduces the efficiency of the filter. To improve the efficiency the filter tubes need to be cleaned. For cleaning the tubes the whole filtration plant needs to shut down which ends up with loss of production.

\subsection{Advancement in Filtration Process}

To reduce the production losses and scheduled losses in the system a new system has been incorporated which reduces the compulsion of shut down of entire plant line for cleaning of filter tubes and also increases the overall productivity of the plant. In this system back pressure is applied in the filter tubes for cleaning purpose. The newly designed system is divided into two compartments as shown in fig.1 (a). Every pressure cycle is of total 12 seconds from which for first 5 seconds, one of the compartments receives a back pressure while the second compartment is still in the influence of positive pressure. For next $1 \mathrm{sec}$ no pressure is applied to any of the Tubesheet surfaces and then for next 5 seconds the pressure application is reversed. This ensures cleaning of filters without stopping the plant.

\subsection{Pressure Cycle}

Fig. 1 (a) shows the schematic view of filter vessel with two compartments.

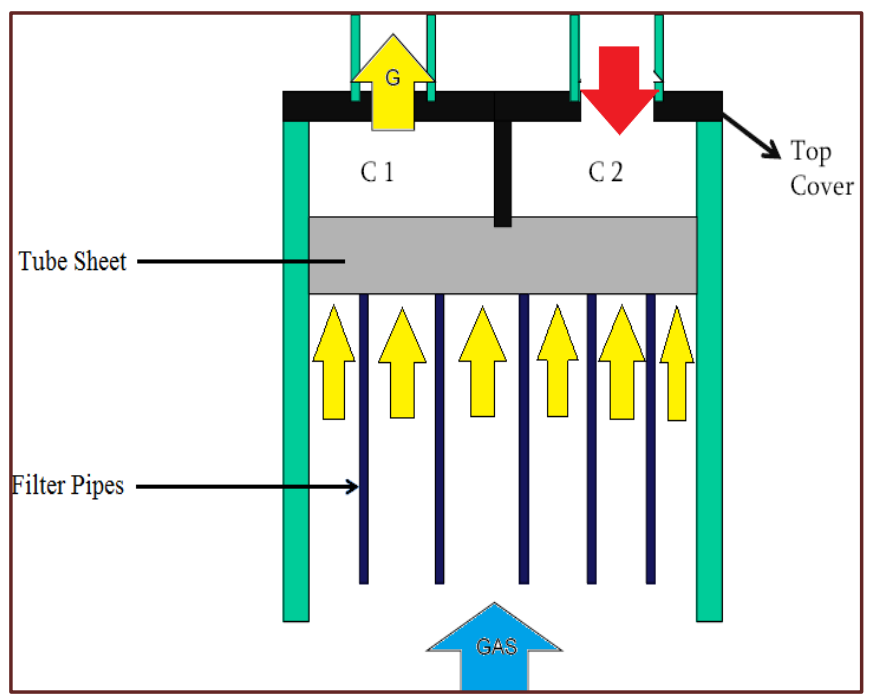

Fig. 1 (a) First Half of Pressure Cycle

0-5 seconds: - Gas enters from the bottom end, gets filtered from the ceramic filter tubes and passes into compartments $\mathrm{C} 1$ whereas compartment $\mathrm{C} 2$ in under the influence of backpressure as shown in the fig above.Due to the back pressure applied deformation of tubesheet takes place at compartment $\mathrm{C} 2$ 
5-6Seconds: - No pressure is applied on either of the sides of Tubesheet. There will be no deformation of tubesheet in this phase.

6-11 seconds: - Gas enters from the bottom end, gets filtered from the ceramic filter tubes and passes into compartments $\mathrm{C} 2$ whereas compartment $\mathrm{C} 1$ is now under the influence of backpressure as shown in the fig 1(b).

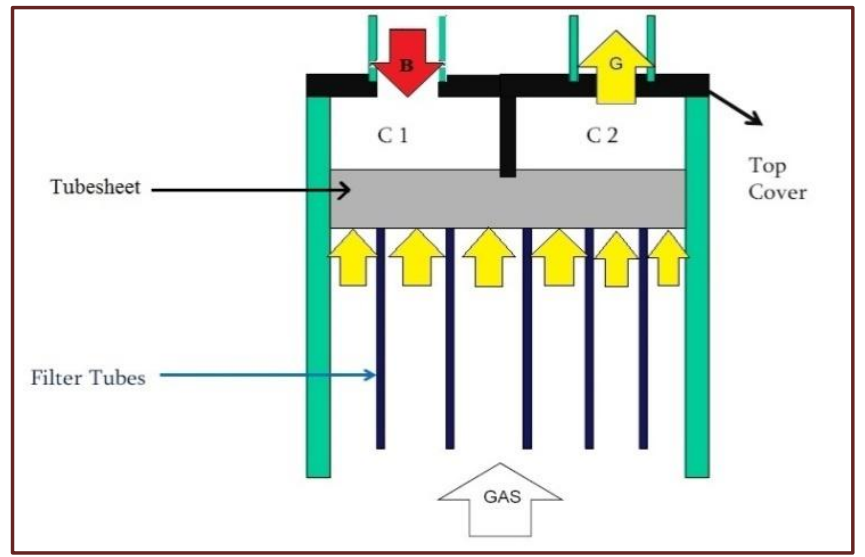

Fig 1 (b) Second half of Pressure Cycle

11-12 Seconds: - In this phase, no pressure is applied on either of the sides of Tubesheet. There will be no deformation of tubesheet in this phase.

The process repeats itself over and over again. However one of the crucial components is the filter sheet itself. This sheet stress reversals from positive to negative and is susceptible to fatigue.

\section{DESIGN CALCULATIONS}

Referring the guidelines provided by the client, the dimensions of the tubesheet were finalized. The parameters provided by the client for design of tubesheet are as follows.

Table 2 Input parameters for tubesheet design

\begin{tabular}{|l|l|l|l|}
\hline $\begin{array}{l}\text { Sr. } \\
\text { No. }\end{array}$ & $\begin{array}{l}\text { Parameter } \\
\text { Description }\end{array}$ & Notations & Given Value \\
\hline 1 & Internal Pressure & $\mathrm{P}$ & $0.14 \mathrm{MPa}$ \\
\hline 2 & External Pressure & $\mathrm{P} 0$ & Atmospheric \\
\hline 3 & Process Volume & $\mathrm{Vp}$ & $126 \mathrm{cu}$ m \\
\hline 4 & $\begin{array}{l}\text { Expected } \\
\text { Stagnant Volume }\end{array}$ & $\mathrm{Vs}$ & Not Specified \\
\hline 5 & $\begin{array}{l}\text { Buffer Volume } \\
\text { Requirement }\end{array}$ & $\mathrm{Vb}$ & Not Specified \\
\hline 6 & $\begin{array}{l}\text { Tube Porosity } \\
\text { Volume }\end{array}$ & $\mathrm{Tp}$ & 70 \\
\hline 7 & Tube Length & $\mathrm{TL}$ & $5.5 \mathrm{~m}$ \\
\hline 8 & $\begin{array}{l}\text { Radius of tube } \\
\text { sheet }\end{array}$ & $\mathrm{r}$ & $2 \mathrm{~m}$ \\
\hline 9 & Tube Diameter & $\mathrm{Td}$ & $0.15 \mathrm{~m}$ \\
\hline
\end{tabular}

Calculated dimensions were confirmed from the client and corrections suggested by the client were implemented in the design of tubesheet.
The finalized dimensions of the tubesheet were as follows:Thickness of Tubesheet $-150 \mathrm{~mm}$

Ligament Efficiency - 0.16

Number of Holes on the tubesheet- 490

\section{ANALYSIS OF TUBESHEET}

Different analyses were performed on the tubesheet for its fatigue life predictions. Before analyzing the tubesheet in transient module, the convergence analysis was performed on it for predicting the most acceptable number of nodes at which the value of stress will be maximum. Following boundary conditions were followed during analysis of tubesheet for convergence purpose.

\subsection{Boundary Conditions for Convergence:}

Case1: Tubesheet analysis with self-weight and gravity acting downwards

Case 2: Tubesheet analysis with gravity acting downwards and design load (0.175 Mpa) acting in opposite direction of gravity

Case 3: Tubesheet analysis with gravity acting downwards and back pressure $(0.145 \mathrm{Mpa})$ acting in the direction of gravity

Case 4: Tubesheet analysis with both positive and negative pressures acting on it.

Tubesheet was analyzed for above mentioned cases by changing the element types. Tetrahedron Elements and Hexdominant Elements were used to get the maximum deflections and maximum stresses. Analyses were carried out varying the number of nodes and the size of elements. Rise of 50000 nodes was kept in every proceeding analysis. Highest number of nodes for analysis was selected as 3, 50,000 nodes. Below are the results of analysis using Hexdominent and Tetrahedron elements for different boundary conditions.

\subsection{Results of Convergence Analysis}

\subsubsection{Tetrahedron Element}

Table 3.2.1 (a) Max stress and Deformation values for Tet element

\begin{tabular}{|l|l|l|l|l|}
\hline $\begin{array}{l}\text { Sr. } \\
\text { No. }\end{array}$ & $\begin{array}{l}\text { Boundary } \\
\text { Condition }\end{array}$ & $\begin{array}{l}\text { Number } \\
\text { of Nodes }\end{array}$ & $\begin{array}{l}\text { Maximum } \\
\text { Stress }\end{array}$ & $\begin{array}{l}\text { Maximum } \\
\text { Deformation }\end{array}$ \\
\hline 1. & Case 1 & 250544 & 38.361 & 0.82115 \\
\hline 2. & Case 2 & 250225 & 35.013 & 0.71512 \\
\hline 3. & Case 3 & 250225 & 99.829 & 2.1 \\
\hline 4. & Case 4 & 250544 & 62.146 & 1.0212 \\
\hline
\end{tabular}




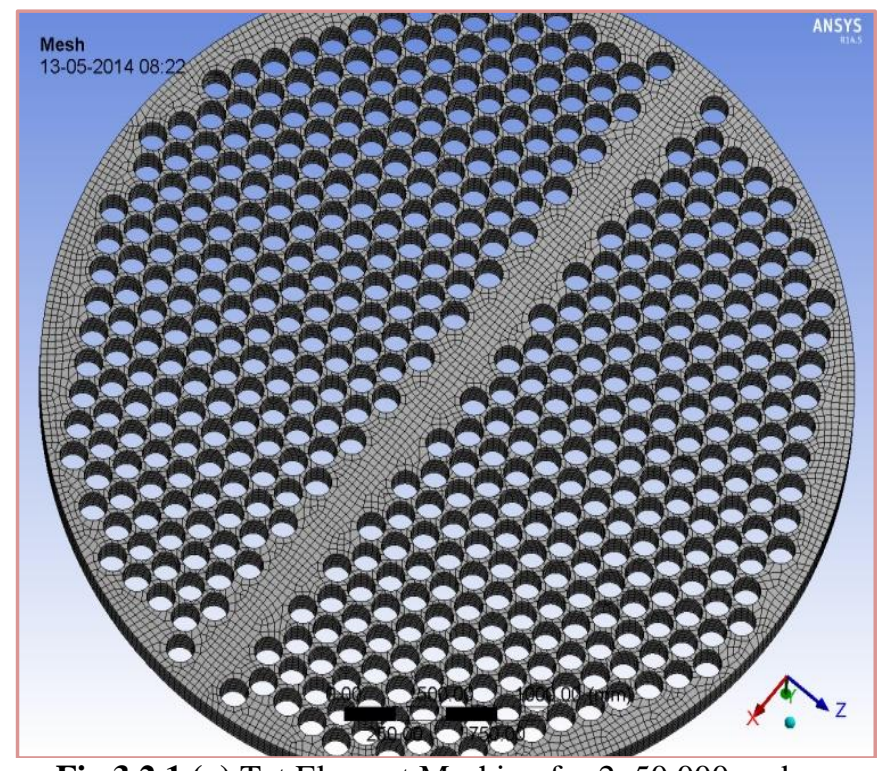

Fig 3.2.1 (a) Tet Element Meshing for 2, 50,000 nodes

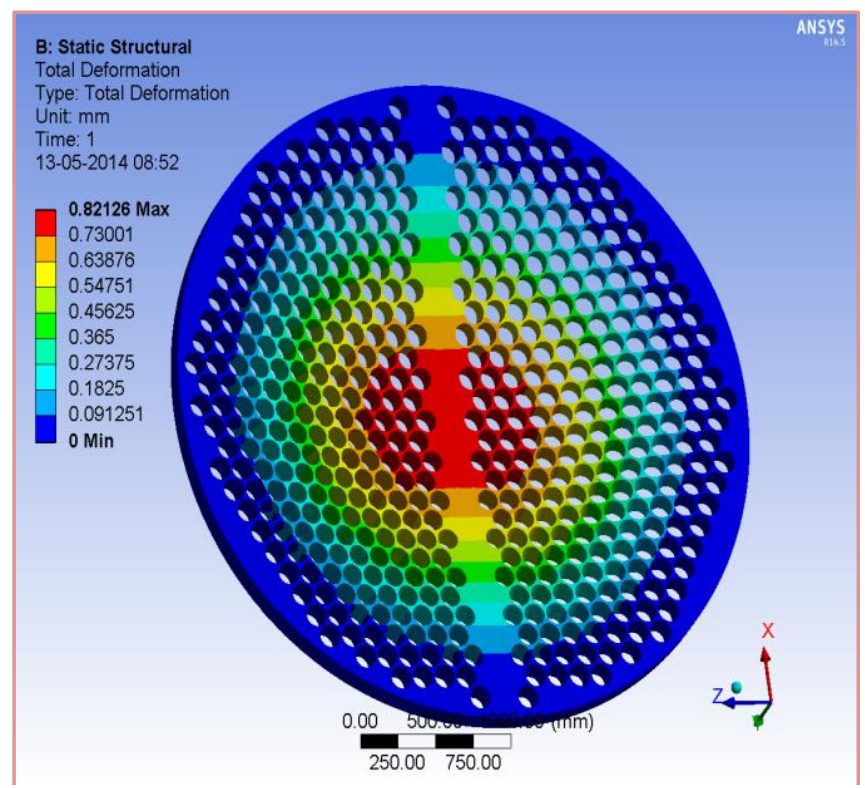

Fig 3.2.1 (b) Case1- Tet Element Maximum Deformation

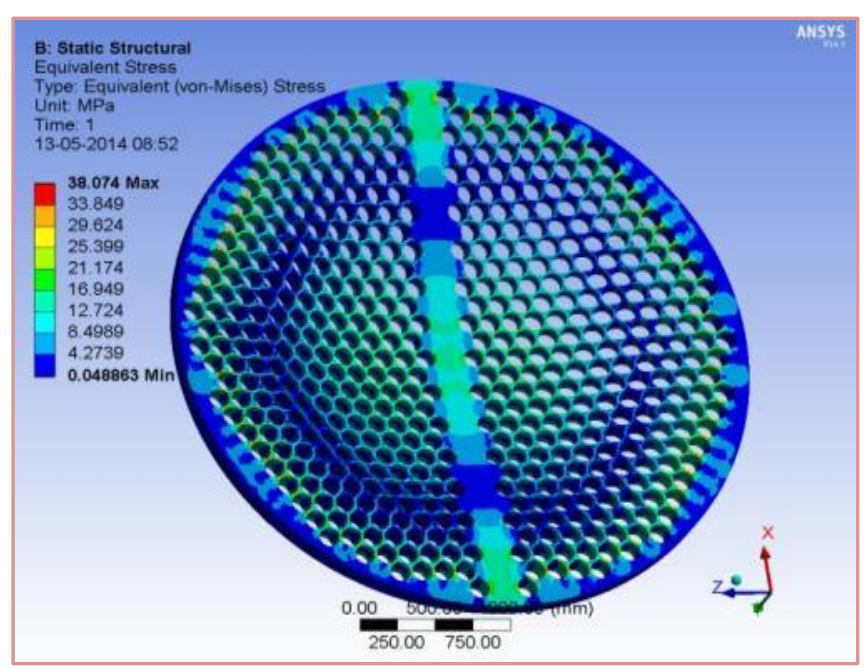

Fig 3.2.1 (c) Case1- Tet Element Maximum Stress

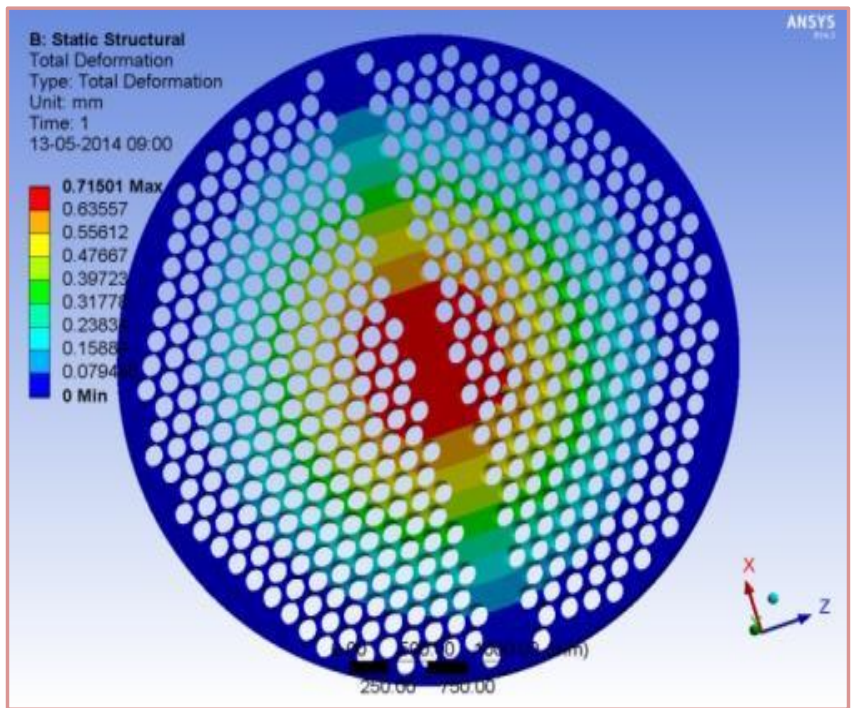

Fig 3.2.1 (d) Case2- Tet Element Maximum Deformation

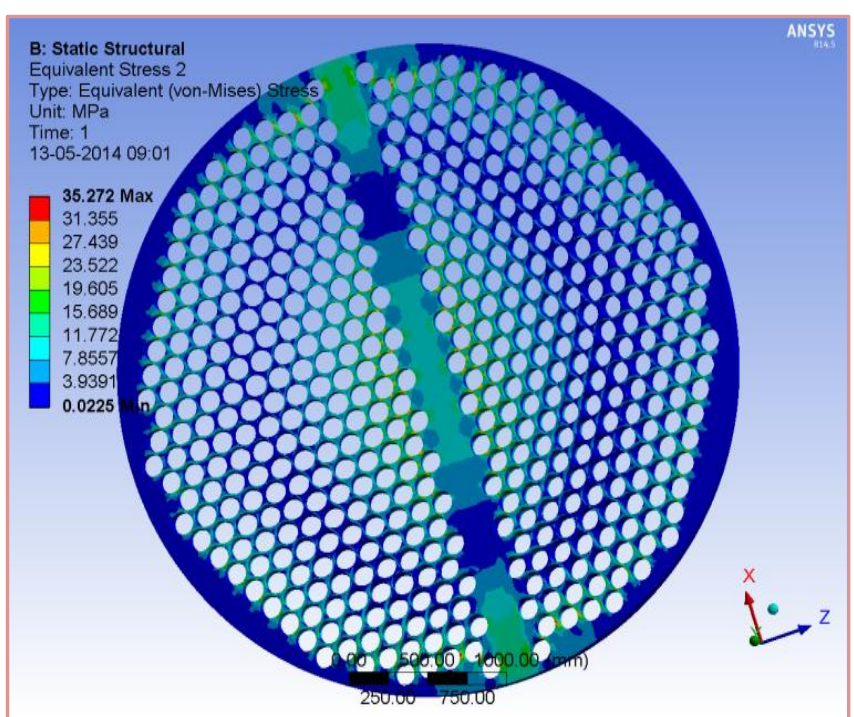

Fig 3.2.1 (e) Case2- Tet Element Maximum Stress

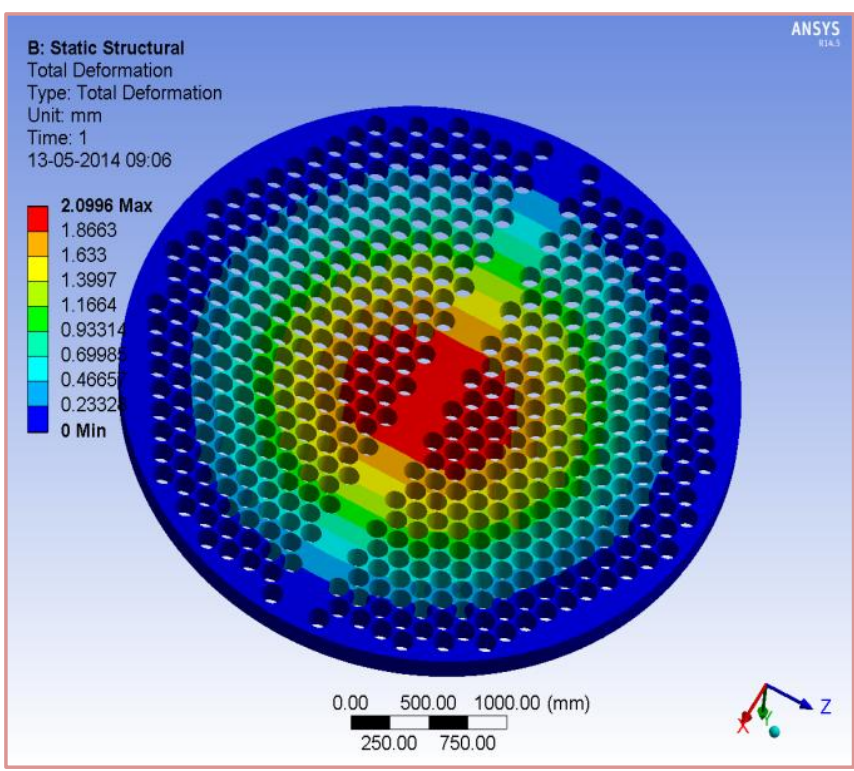

Fig 3.2.1 (e) Case3- Tet Element Maximum Deformation 


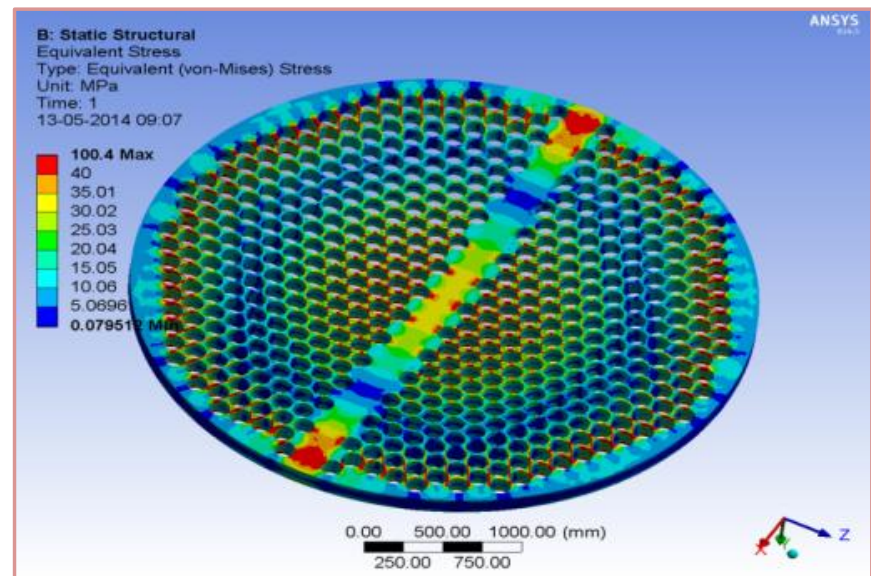

Fig 3.2.1 (f) Case3- Tet Element Maximum Stress

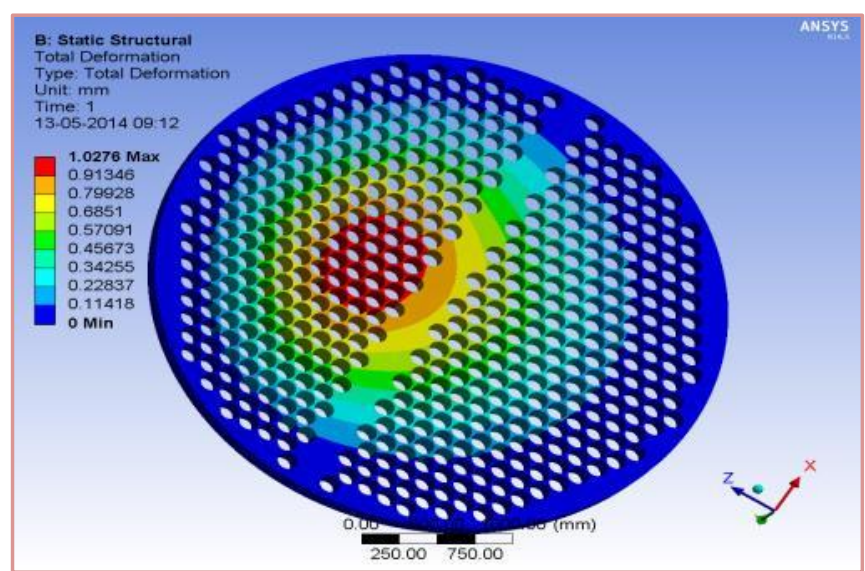

Fig 3.2.1 (g) Case4- Tet Element Maximum Deformation

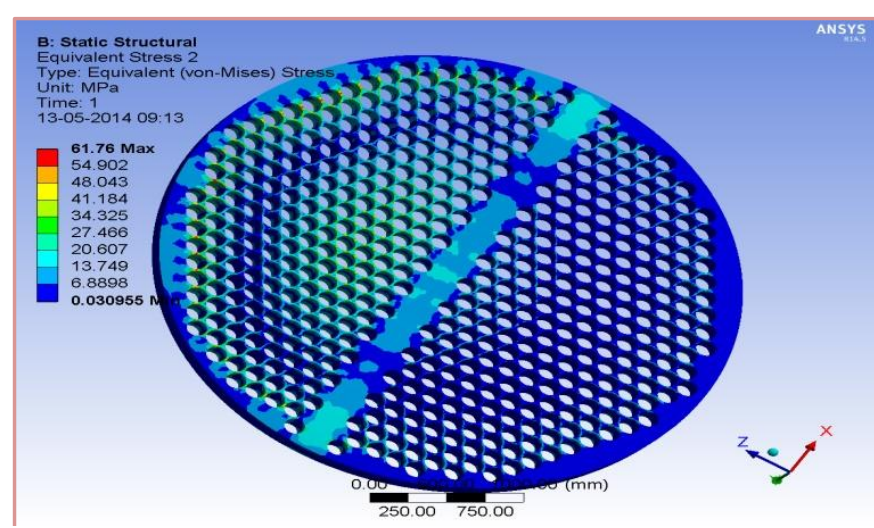

Fig 3.2.1 (h) Case2- Tet Element Maximum Stress

\subsubsection{Hex dominant Element}

Table 3.2.2 (b) Max stress and Deformation values for Hex element

\begin{tabular}{|l|l|l|l|l|}
\hline $\begin{array}{l}\text { Sr. } \\
\text { No. }\end{array}$ & $\begin{array}{l}\text { Boundary } \\
\text { Condition }\end{array}$ & $\begin{array}{l}\text { Number } \\
\text { of Nodes }\end{array}$ & $\begin{array}{l}\text { Maximum } \\
\text { Stress }\end{array}$ & $\begin{array}{l}\text { Maximum } \\
\text { Deformati } \\
\text { on }\end{array}$ \\
\hline 1. & Case 1 & 257292 & 45.794 & 0.82908 \\
\hline 2. & Case 2 & 253498 & 38.719 & 0.72197 \\
\hline 3. & Case 3 & 255655 & 106.13 & 2.1186 \\
\hline 4. & Case 4 & 253676 & 71.465 & 1.039 \\
\hline
\end{tabular}

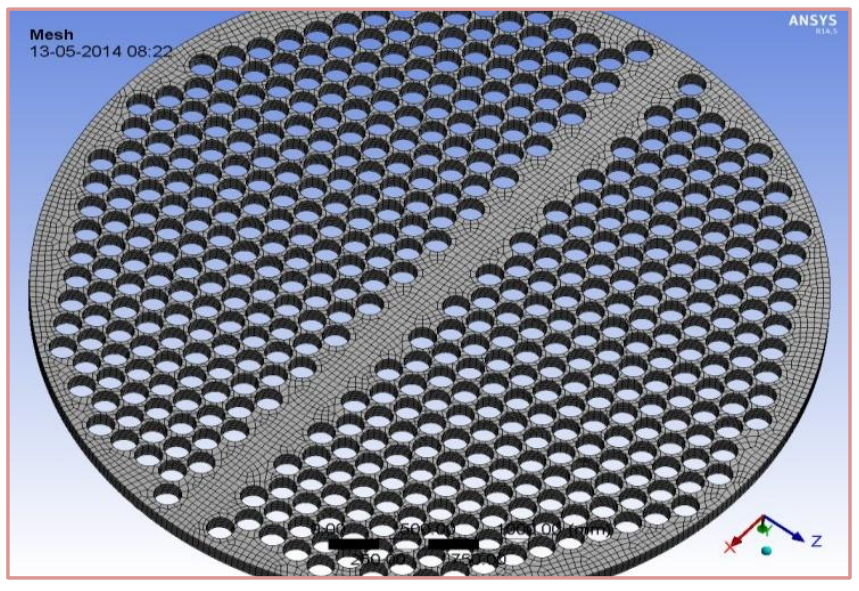

Fig 3.2.2 (g) Hex Element Meshing for 2, 50,000 nodes

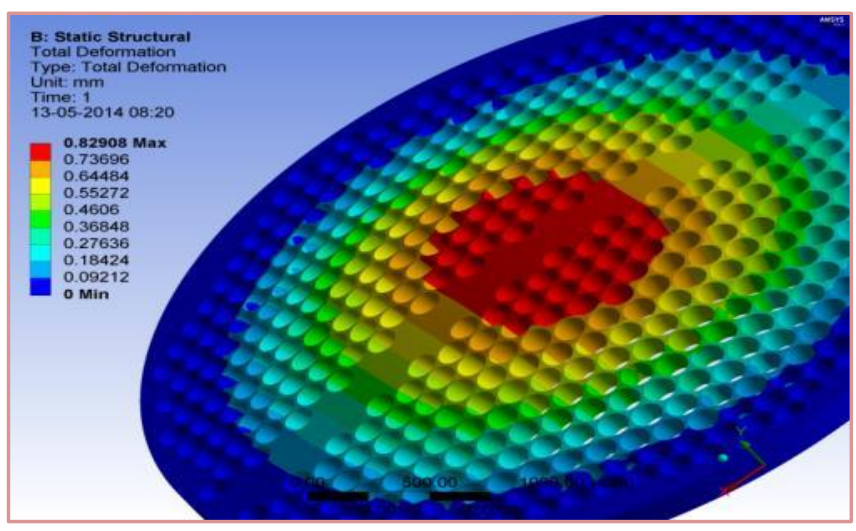

Fig 3.2.2 (h) Case1 - Hex Element Maximum Deformation

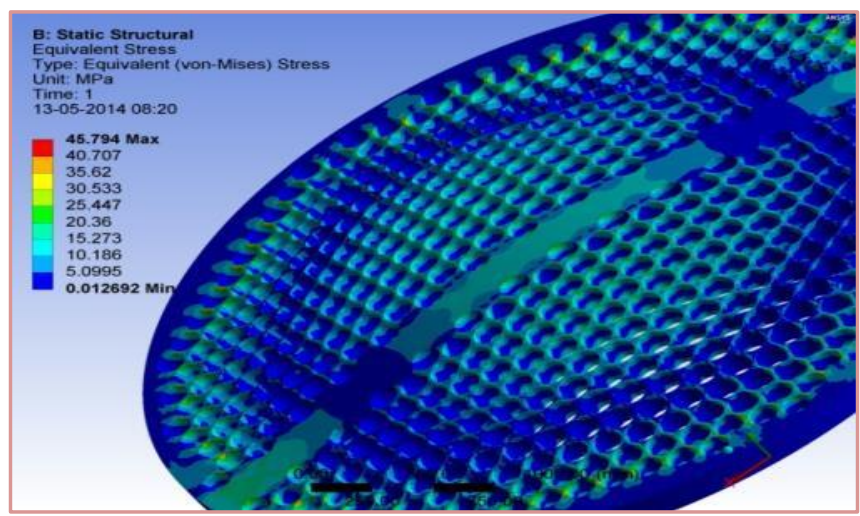

Fig 3.2.2 (i) Case1- Hex Element Maximum Stress

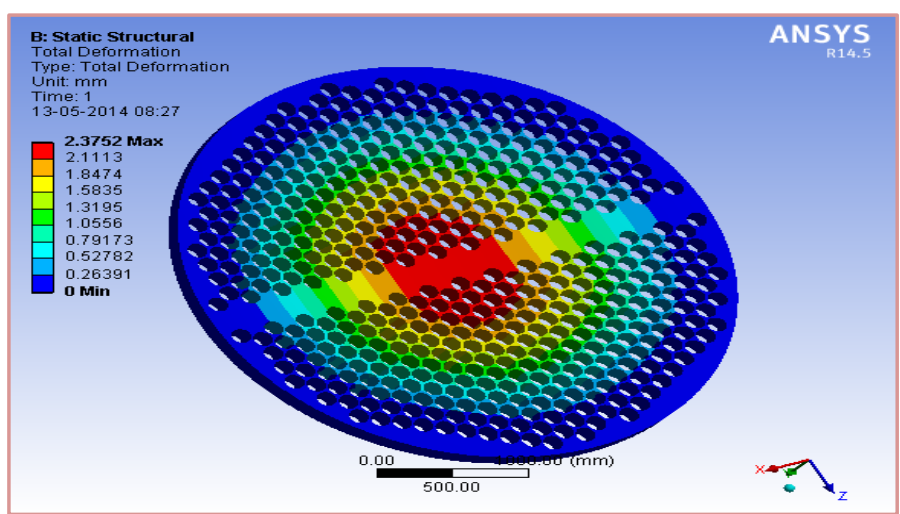

Fig 3.2.2 (j) Case2- Hex Element Maximum Deformation 


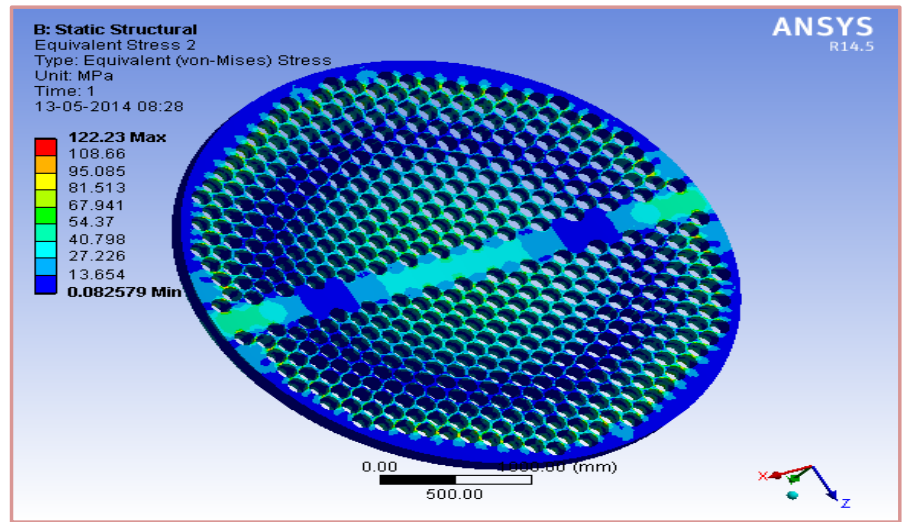

Fig 3.2.2 (k) Case2- Hex Element Maximum Stress

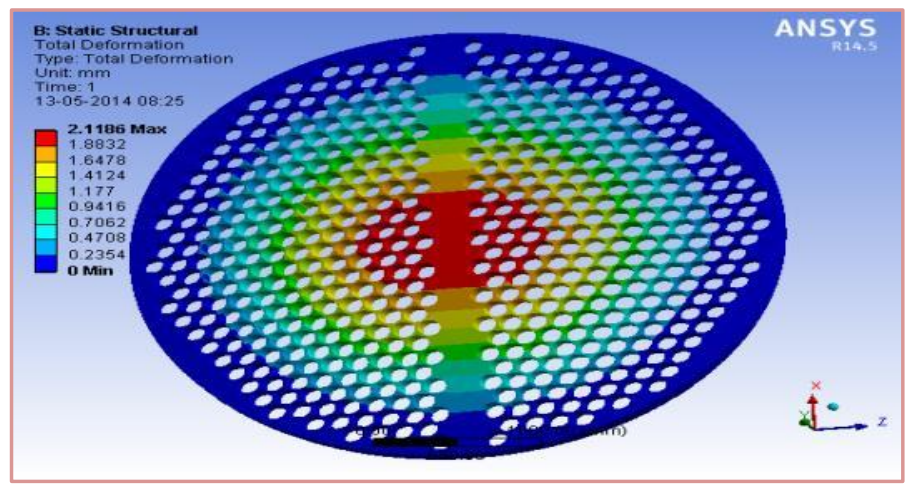

Fig 3.2.2 (l) Case3- Hex Element Maximum Deformation

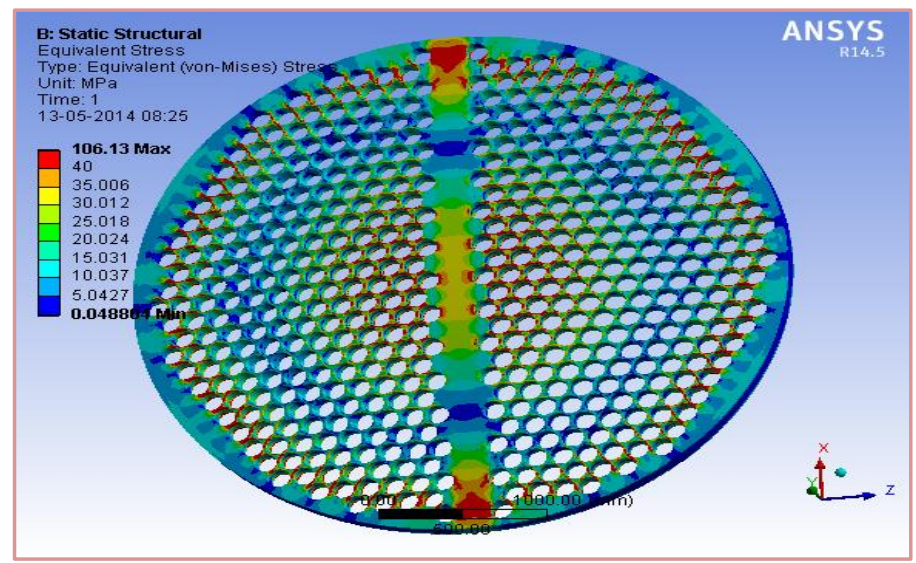

Fig 3.2.2 (m) Case3- Hex Element Maximum Stress

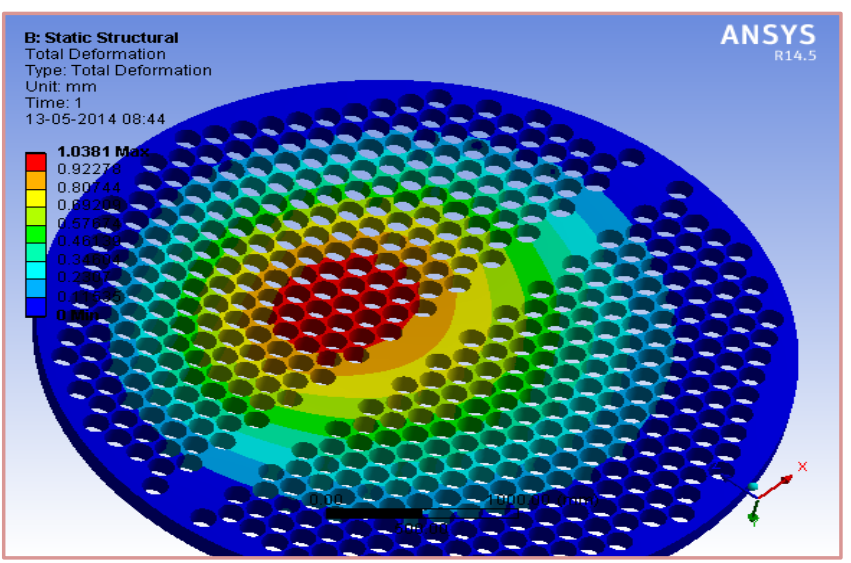

Fig 3.2.2 (n) Case4- Hex Element Maximum Deformation

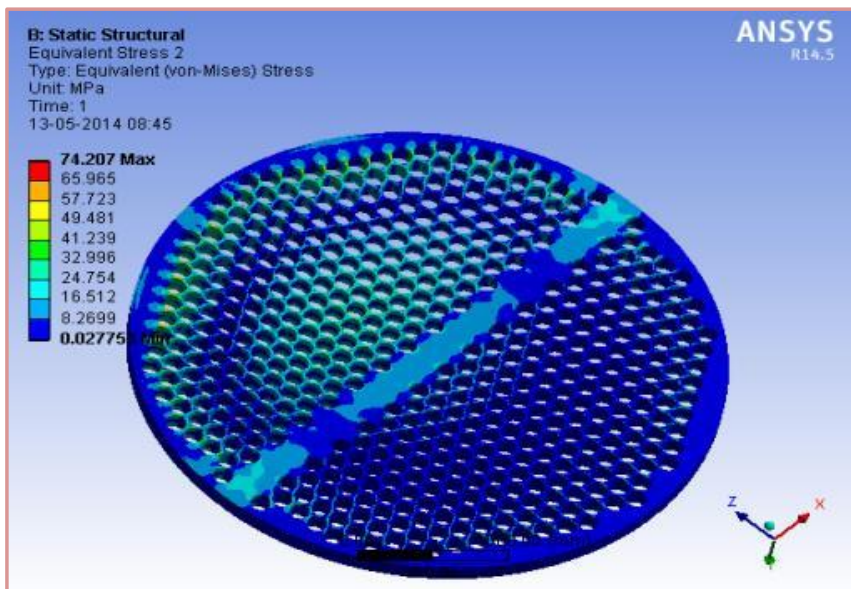

Fig 3.2.2 (o) Case3- Hex Element Maximum Stress

From the convergence analysis it was found that, at 2, 50,000 numbers of nodes the stress values are maximum and after that the values of stresses are gradually reducing.

Also the Hex dominant elements are better than Tetrahedron elements for analysis purpose and have better meshing as compared to Tetrahedron element. Considering the advantages of Hex dominant element, further Transient analysis was carried out using the same.

\subsection{Transient Dynamic Analysis}

After the convergence analysis 2, 50, 000 number of nodes with hex dominant elements were fixed and further analysis were performed.

\subsubsection{Boundary Conditions for Transient Analysis}

0 - 5 Seconds: - Pressure of 0.14 Mpa was applied on the left bottom half face whereas $0.145 \mathrm{Mpa}$ was applied on the right top half face of the tubesheet.

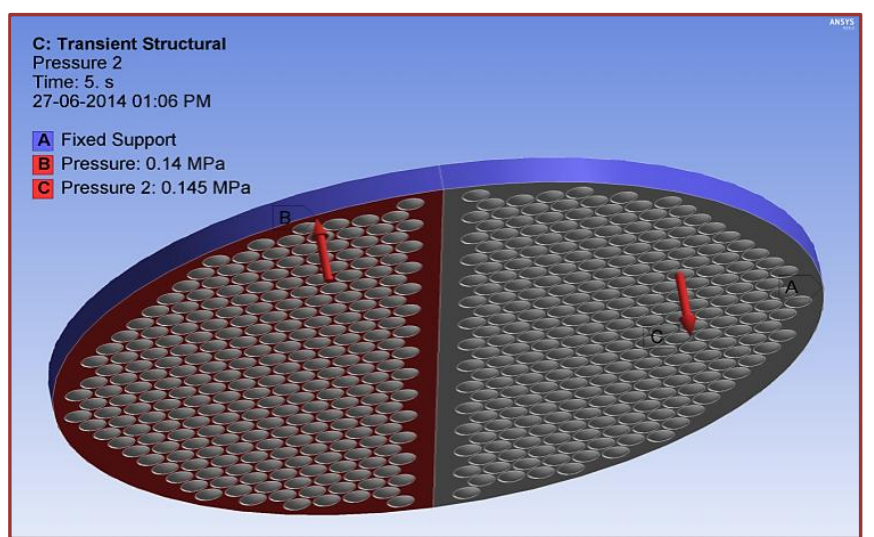

Fig 3.3.1 (a) Load applied in 1st Half of Load Cycle

5 - 6 Seconds: - No pressure was applied on any of the surface.

6- 11Seconds: - Pressure of 0.14 Mpa was applied on the right bottom half face whereas $0.145 \mathrm{Mpa}$ was applied on the left top half face of the tubesheet. 


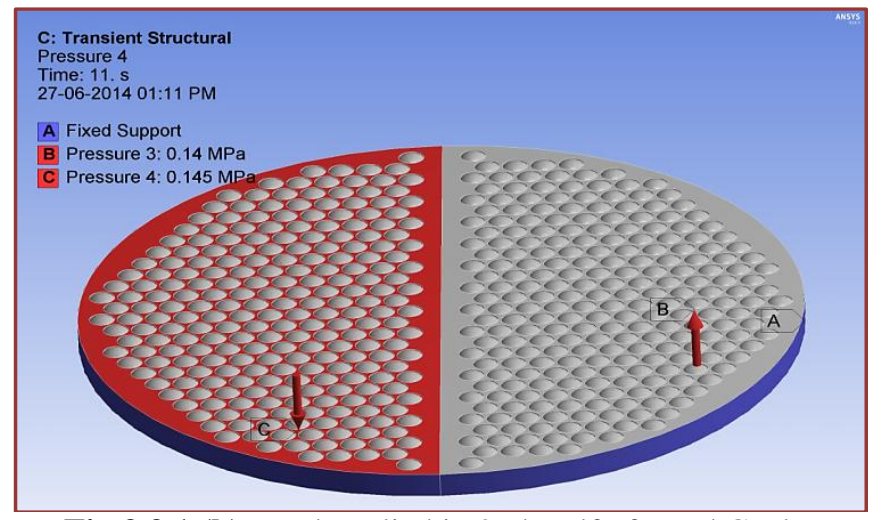

Fig 3.3.1 (b) Load applied in 2nd Half of Load Cycle

11 - 12Seconds: - No pressure was applied on any of the surface.

\subsubsection{Transient Analysis Results}

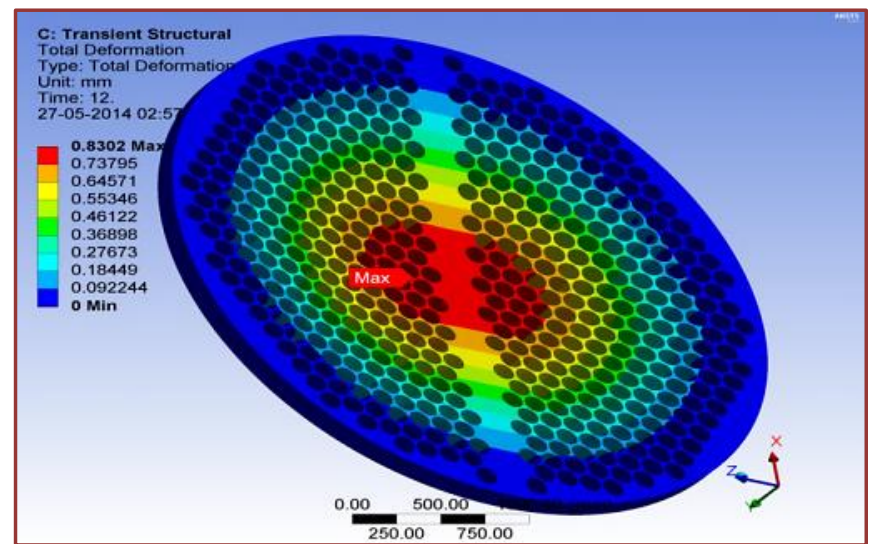

Fig 3.3.2 (a) Maximum Deformation of tubesheet for single cycle with $2.5 \mathrm{~L}$ nodes

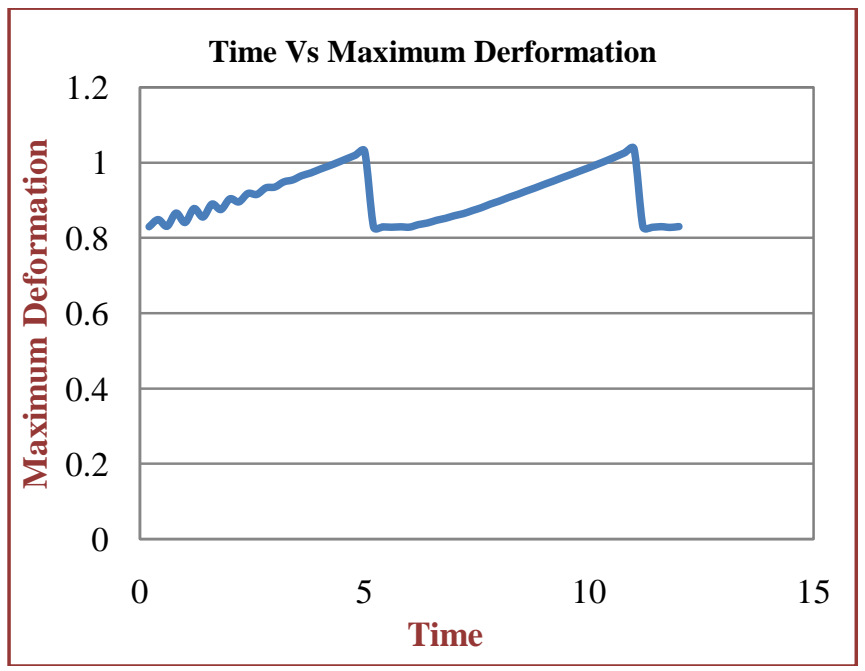

Fig 3.3.2 (b) Time Vs Maximum Deformation graph of tubesheet for single load cycle

The above graph shows the values of maximum deformation of the tubesheet for the applied pressure conditions with respect to time.

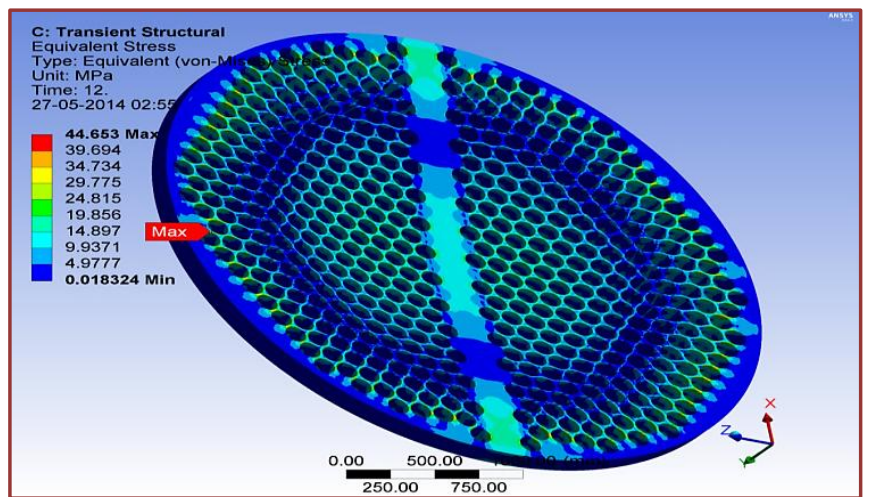

Fig 3.3.2 (c) Maximum Stresses in Tubesheet for single cycle with $2,50,000$ nodes

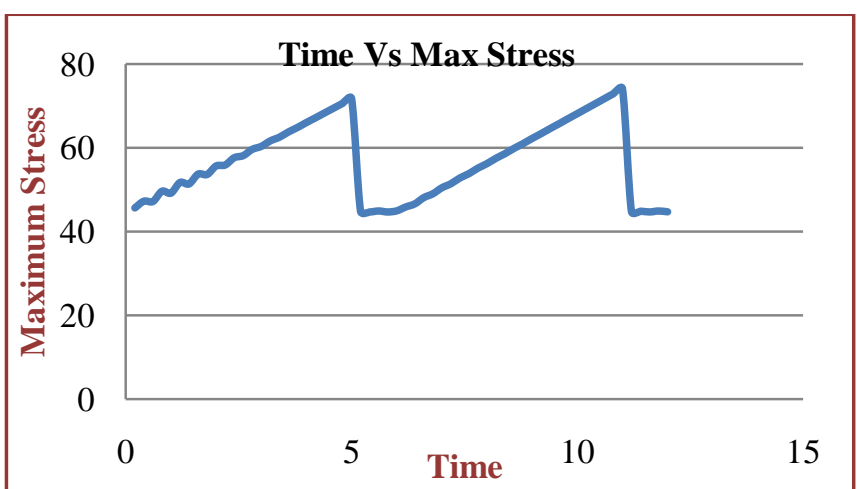

Fig 3.3.2 (d) Time Vs Maximum Stress graph for tubesheet with single cycle

The above graph shows the values of maximum stress in the tubesheet for the applied pressure conditions with respect to time.

\subsection{FATIGUE LIFE CALCULATIONS FOR TUBE SHEET}

\subsubsection{Cyclic Data [10]}

$\mathrm{dSpk}-$ Range of Primary + Secondary + Peak $=27 \mathrm{~N} / \mathrm{mm} 2$ = 3916.30899 Psi

$\mathrm{Kf}-$ Fatigue Strength reduction factor $=2.50$

$\mathrm{m}$ - Material constant used for the fatigue knock down factor $=3.00$

$\mathrm{n}$ - Material constant used for the fatigue knock down factor $=0.20$

S - Material Allowable Stress $=20015.207$ Psi

Sy - Material yield Strength $=38426.29823$ Psi

Tav- Average Cycle temperature $=150$

Et - Modulus of Elasticity at Tav $=29030000$

Fatigue Penalty Factor [10]

$\mathrm{Sps}=3 * \mathrm{~S}$ or $2 * \mathrm{Sy} \ldots \ldots \ldots$ (Whichever is maximum)

$\mathrm{Sps}=76852.59646$

Kek $1=1$

Kek $2=1+(1-n) /(n(m-1))(d S p k / S p s-1)$

Kek $2=-0.89808$

Kek $3=1 /$ n

Kek $3=5$

Kek $=$ if $(\mathrm{dSpk}<\mathrm{Sps})$ then Kek 1 
Therefore, $\mathrm{Kek}=1$

Permissible cycle life

SaltK $=(\mathrm{Kf} * \mathrm{Kek} * \mathrm{dSpk}) / 2$

SaltK $=4895.386$ Psi $\ldots$ (Alternating stress in Tube sheet)

SaltK $=33.7525 \mathrm{~N} / \mathrm{mm} 2$

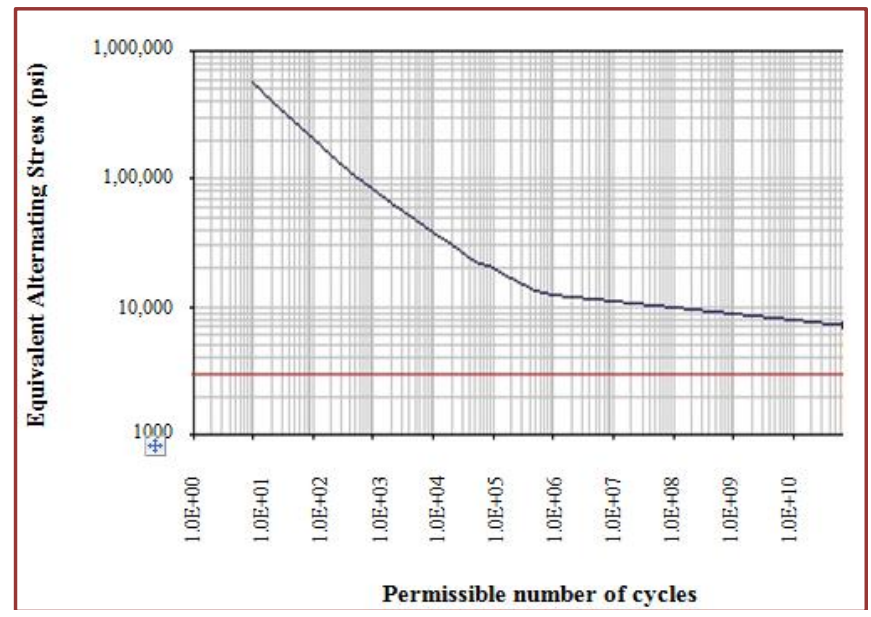

Fig 3.4 (a) Permissible Number of Cycles Vs Equivalent alternating Stress for tubesheet with 2, 50,000 nodes [10]

From the graph(3.4 (a)) of permissible number of cycles Vs equivalent alternating stress it can be observed that for the calculated value of alternating stress i.e. 4895.386 psi, the model can sustain for more than E11 number of load cycles. Hence the tube sheet can sustain the alternating stress for infinite life.

\section{EXPERIMENTAL VALIDATION}

\subsection{Hydro Test}

The tubesheet was checked for the maximum deformation under the fluid pressure of $0.173 \mathrm{Mpa}$, and working at 27 $\operatorname{deg} \mathrm{C}$. The holes of tubes were blocked with the help of GR 3084 Plugs.

To measure the deformation (LC 4C1 X) HBM type of Strain gauge was located at the center of the Filter Tubesheet. The table below shows the values of deformation obtained analytically as well as experimentally and the percentage of error.

Table 4.1 Experimental Vs Analysis Results

\begin{tabular}{|c|c|c|c|c|}
\hline $\begin{array}{l}\text { Sr. } \\
\text { No. }\end{array}$ & Test & $\begin{array}{l}\text { Max } \\
\text { Deformatio } \\
\mathrm{n} \text { in } \mathrm{mm} \text { by } \\
\text { FE Analysis }\end{array}$ & $\begin{array}{l}\text { Max } \\
\text { Deformation } \\
\text { in mm by } \\
\text { Measurement }\end{array}$ & $\begin{array}{l}\% \\
\text { Error }\end{array}$ \\
\hline 1 & $\begin{array}{l}\text { Hydro } \\
\text { Test at } \\
0.173 \\
\text { Mpa } \\
\text { Pressure } \\
\end{array}$ & 4.3903 & 4.9 & $10.4 \%$ \\
\hline 2 & $\begin{array}{l}\text { Under } \\
\text { self- } \\
\text { weight }\end{array}$ & 0.82867 & 0.86 & $3.64 \%$ \\
\hline
\end{tabular}

\begin{tabular}{|l|l|l|l|}
\hline and & & \\
gravity & & & \\
condition & & & \\
at 0 Mpa & & & \\
pressure & & & \\
\hline
\end{tabular}

\section{CONCLUSION AND FUTURE SCOPE}

\subsection{Conclusion}

The project deals with the determination of the fatigue life of tubesheet which is one of the major components in industrial filter vessels. The tubesheet have to sustain the static load of the filter tubes as well as the selfweight due to gravity. In the current study a new system exerting back pressure was implemented due to which the tubesheet was under alternating stresses causing the tubesheet to undergo fatigue.

To increase the accuracy of results the convergence analyses were performed with different boundary conditions to get the proper number of nodes and element size for further analysis.

Convergence analysis gave the following conclusion:-

a) 2, 50, 000 nodes should be used for the further transient analysis as the value of stress is maximum for 2, 50, 000 nodes for different boundary conditions.

b) Hexdominent Element should be used as it shows quality meshing results.

Transient dynamic analyses were performed on the tubesheet to check the maximum deformation and stresses at various instant of time during the load cycle. The transient dynamic analysis of tubesheet with 2, 50, 000 nodes was performed to get the maximum deformation and maximum stresses in the tubesheet. Using the maximum stress values the fatigue life of tubesheet was calculated which came out as infinite life.

\subsection{Future Scope}

The tubesheet analyzed here was of $150 \mathrm{~mm}$ thickness for which the calculated fatigue life is infinite number of load cycles. Also the tubesheet was checked under extreme loading condition. The thickness of the tubesheet can be reduced as per requirement. Also other parameters can be changed and analyzed.

\section{REFERENCES}

[1] Dr. Enrique Gomez, Mr. Roberto Ruiz 'ASME SECTION III Stress Analysis of a Heat ExchangerTubesheet With a Misdrilled Hole and Irregular or Thin Ligaments' [Conference] // ASME 2013 Pressure Vessel and Piping Conference. - Paris : ASME, 2013.

[2] Giglio M. 'Fatigue Analysis of Different types of Nozzles' [Journal] // International Journal of Pressure Vessels and Pipings. 
[3] Liu Minshan 'Stress analysis of $\Omega$-tubesheet in waste heat boiler' [Journal]. - [s.1.] : Journal of Pressure Equipment and Systems, 2006.

[4] Myung Jo Jhung Jong Chull Jo 'Equivalent Material Propeties of Perforated Plate with Triangular or Square Penetration Pattern For Dynamic Analysis' [Journal]. - [s.l.] : Nuclear Engineering and Technology, 2006. - Vol. 62.

[5] Naik Shweta 'Thickness and shape optimization of Filter Tubesheet by Non Linear FEA' [Journal]. [s.l.] : Global Journals Inc. (USA), 2013. - 1 : Vol. 13.

[6] Nandagopan O. R. 'Non Linear Behaviour of Perforated Plate with Lining' [Journal]. - [s.l.] : Defense Science Journal, 2012. - Vol. 62.

[7] R. D. Patil Dr. Bimlesh Kumar 'An Approach to Finite Element Analysis of Boiler Tubesheet' [Journal]. - [s.1.] : American Journal of Engineering Research, 2013. - 08 : Vol. 02.

[8] W. J. O'Donnell B. F. Langer 'Design of Perforated Plates' [Journal]. - [s.1.] : ASME, 1962. - Vol. 84.

[9] 2010 ASME Boiler and Pressure Vessel Codes Section VIII Division II.

[10] Finite Element Analysis report- VIII-1 by Pressure Vessel Engineering. Ltd 